\title{
PERANAN FREKUENSI PENYIANGAN MANUAL TERHADAP PENURUNAN RESIKO KEBAKARAN PADA HUTAN TANAMAN
}

\author{
The Influence of Manual Weeding Frequency on Reducing Fire Risk in Forest Plantation
}

\author{
Acep Akbar \\ Balai Penelitian Kehutanan Banjarbaru \\ Jl. Sei Ulin No. 28 B Banjarbaru 70714, Telp. (02511) 4772085, Fax. 4773222
}

Naskah masuk : 12 Februari 2007 ; Naskah diterima : 28 Mei 2007

\begin{abstract}
One of the important aspects in the establishment of a certain low fire risk forest plantation is tending treatment such as weeding. This experiment was emphasized to find out the influence of several manual weeding frequency of four trees plantation by total liberation treatment on weed height, fresh weight of biomass, weed density, forest plantation growth and survival after burning. Experiment was arranged in single factor consist of gradually weeding every 6,5,4, 3 month and randomized complete block design in four replication. The results of research showed that weeds and plant growth was vary as effect of weeding treatment which determine fire risk. Weeding frequent treatment significantly affected on weeds height, density and its fresh weight. On the other hand, weeding treatment mentioned significantly influenced tree growth, length of burnt stem and survival of the plantation after burning as well. Weeding every three month produce the lowest weed height $(33,9 \mathrm{~cm})$ and its fresh weight (121,9 gram) and also the lowest of stem burned $(64,8 \mathrm{~cm})$. So that, it is identical with resistance of forest to fire.
\end{abstract}

Key Words : Forest plantation, weeding, fire risk, weed

\begin{abstract}
ABSTRAK
Salah satu aspek penting di dalam membangun suatu model hutan tanaman beresiko kebakaran rendah adalah melakukan aktivitas pemeliharaan. Penelitian model hutan ini memfokuskan pada pengaruh beberapa tingkat frekuensi penyiangan tebas total gulma bawah tegakan hutan tanaman terhadap tinggi gulma, bobot basah gulma, kerapatan, pertumbuhan dan ketahanan hidup tanaman terhadap kebakaran. Melalui eksperimen faktor tunggal yang terdiri dari penyiangan setiap 6, 5,4 dan 3 bulan yang diatur dengan model rancangan acak kelompok telah dihasilkan keragaman respon pertumbuhan gulma dan tanaman akibat penyiangan sehingga berhubungan dengan kerawanan kebakaran. Data menunjukan bahwa tingkat frekuensi penyiangan berpengaruh terhadap tinggi, kerapatan gulma dan berat basahnya. Sedangkan perlakuan penebasan tersebut juga berpengaruh terhadap pertumbuhan tanaman pokok, panjang hangus batang setelah terbakar serta kematian tanaman akibat kebakaran. Penyiangan tanaman setiap 3 bulan telah menghasilkan tinggi $(33,9 \mathrm{~cm})$ serta berat basah $(121,9$ gram) gulma terendah dan panjang hangus batang pohon terpendek $(64,8 \mathrm{~cm})$ yang identik dengan ketahanan hidup pohon terhadap kebakaran.
\end{abstract}

Kata kunci : Hutan tanaman, penyiangan, resiko kebakaran, gulma. 


\section{PENDAHULUAN}

Revitalisasi sektor kehutanan khususnya industri kehutanan memerlukan banyak pembangunan hutan tanaman agar hutan tersebut menjadi penyedia bahan baku industri yang strategis. Pada era rehabilitasi dan konservasi hutan sekarang ini, kayu tidak lagi diharapkan datang dari hutan alam yang sudah rusak parah, melainkan dari hutan tanaman yang terkelola secara berkelanjutan.

Kebakaran pada hutan tanaman di Indonesia selama ini baik berupa hutan tanaman industri (HTI) maupun tanaman reboisasi lebih banyak disebabkan oleh kondisi vegetasi gulma bawah tegakan tanaman yang terlalu rapat dan tinggi sehingga sangat mendukung masuknya api liar yang datang dari luar areal hutan. Hutan tanaman merupakan areal yang sangat rawan kebakaran apabila tidak dikelola secara intensif. Jika kita mencermati potret kejadian kebakaran terbesar yaitu pada tahun 1997 dan 1998 maka tampak bahwa hutan tanaman menempati urutan luasan terluas keempat (955.988 ha) setelah hutan alam dataran rendah (3.598.880 ha), lahan pertanian (3.496.808 ha) dan hutan rawa gambut (2.124.000 ha) (IFFM, 2003).

Telah menjadi anggapan umum bahwa kejadian kebakaran di Indonesia sering berhubungan dengan pembakaran ladang dan peremajaan rumput yang telah rutin dilakukan oleh para peladang dan peternak sistem lepas setiap tahun. Saat ini ada kecenderungan juga luas garapan ladang setiap orang meningkat akibat adanya perubahan tujuan penghasilan dari kebutuhan hidup sehari-hari menjadi tujuan bisnis yang lebih besar (Saharjo, 2006). Namun demikian sekalipun banyak api-api liar yang masuk ke dalam areal, ia tidak akan menjadi kebakaran besar apabila tanaman terpelihara dari bahan bakar potensial bawah tegakan yang melimpah. Untuk mengurangi jumlah bahan bakar potensial bawah tegakan yang perlu diterapkan adalah perlakuan penyiangan ideal yang harus dilaksanakan agar gulma yang hidup di bawah tegakan tanaman menjadi terpelihara sependek mungkin, untuk itu penentuan frekuensi penyiangan terhadap gulma bawah tegakan perlu diteliti. Dengan indikator tinggi dan berat basah gulma yang mengalami rejuvenasi pasca penyiangan diharapkan dapat menggambarkan api yang akan terjadi apabila tanaman terbakar. Api yang timbul di lahan alang-alang tingginya hampir mencapai dua kali tinggi alang-alang saat terjadi kebakaran di musim kering (Sagala, 1992). Kegiatan penyiangan melalui penebasan gulma akan menjamin keamanan lingkungan dan akan lebih banyak menyerap tenaga kerja dibanding penyiangan menggunakan herbisida. Secara umum frekuensi penyiangan akan ditentukan oleh jenis pohon yang dikembangkan, jarak tanam dan jenis gulma yang tumbuh bawah tegakan. Masing-masing jenis memiliki struktur daun dan sistem percabangan berbeda sehingga menentukan penetrasi cahaya matahari yang masuk ke lantai hutan tanaman. Di sisi lain setiap jenis gulma akan memiliki sifat toleransi berbeda terhadap naungan dan penetrasi cahaya dari atas (Barus, 2003.).

Satu penyebab kebakaran yang nampaknya lebih mudah dikendalikan adalah besarnya muatan bahan bakar bawah dari hutan tanaman. Bahan bakar bawah tegakan hutan tanaman biasanya terdiri dari serasah, vegetasi gulma dan ranting-ranting kering yang rapat pada bagian bawah batang pohon. Pihak pengelola sebaiknya dapat mengalokasikan dana untuk penyiangan gulma yang ideal. Gulma hutan tanaman biasanya terdiri dari rumput dan semak. Penyiangan dimaksud adalah termasuk membersihkan ranting-ranting kering yang rapat pada batang bagian bawah. Pertanyaan yang timbul dalam upaya minimasi bahan bakar adalah berapa kali gulma harus disiang dalam satu tahun agar tercipta kondisi bahan bakar sependek mungkin sehingga jika terjadi api tidak berakibat mematikan atau mengganggu pertumbuhan pohon hutan tanaman. Setiap jenis memiliki karakter tajuk dan lebar daun berbeda. Acacia mangium memiliki tajuk yang tebal dan lebar dengan daun lebar berposisi horizontal. Acacia crassicarpa memiliki tajuk lebar dan tebal tapi daunnya berposisi vertikal bertajuk 
sedang dan tipis dengan daun berlapis agak jarang. Jenis Eucalyptus pellita bertajuk tipis dan sempit dengan kondisi daun kecil dan jarang. Sedangkan Alstonia scholaris bertajuk tipis tetapi berdaun agak lebar.

Perbedaan sifat-sifat daun dan tajuk akan mempengaruhi besar kecilnya penetrasi cahaya masuk ke lantai hutan, sehingga akan mempengaruhi kecepatan pertumbuhan gulma. Untuk memperoleh frekuensi ideal penyiangan diperlukan suatu eksperimen yang dirancang melalui suatu percobaan. Hipotesis percobaan yang dibangun adalah :

1. Kecepatan pertumbuhan kembali dan kerapatan gulma dipengaruhi oleh tingkat keseringan (frekuensi) penyiangan gulma bawah tegakan hutan tanaman.

2. Intensitas penyiangan berpengaruh terhadap tinggi api dan panjang hangus batang saat terjadi kebakaran.

Penelitian ini bertujuan untuk :

a. Mengetahui pertumbuhan dan kerapatan gulma setelah perlakuan penyiangan pada empat jenis pohon hutan tanaman, penyiangan tersebut dilakukan dengan tebas total gulma.

b. Mengetahui pengaruh intensitas penyiangan gulma bawah tegakan hutan tanaman terhadap panjang hangus batang saat terjadi kebakaran.

Sasaran penelitian ini adalah tersusunnya suatu konsep pemeliharaan terbaik khususnya dalam melakukan penyiangan tebas total agar memiliki bahan bakar potensial yang rendah di bawah tegakan sehingga jika api liar masuk ke lantai hutan, ia tidak mematikan tanaman pokok.

\section{BAHAN DAN METODE}

\section{A. Bahan dan Peralatan}

Percobaan dilakukan di hutan penelitian Balai Litbang Hutan Tanaman Indonesia Bagian Timur di Riam Kiwa Kabupaten Banjar, Kalimantan Selatan pada tahun 2005. Pada tahun 2004 hutan penelitian Riam Kiwa telah ditetapkan menjadi Kawasan Hutan Dengan Tujuan Khusus (KHDTK) dengan Surat Keputusan Menteri Kehutanan Nomor SK 75/Menhut-II/2004 tanggal 11 Maret 2004. KHDTK Riam Kiwa memiliki luas 1455 Ha, secara geografis terletak antara 30 21 ' $40^{\prime}$ '-30 23 '30” LS dan $115^{0} 6^{\prime 2} 21^{\prime \prime}$ BT sedangkan secara administratif termasuk dalam Kecamatan Pengaron dan Astambul Kabupaten Banjar, Kalimantan Selatan. Lokasi penelitian berada pada ketinggian 100-150 m dari permukaan laut, tanah terdiri dari kompleks podsolik merah dan podsolik kuning. Temperatur harian rata-rata antara $32-36^{\circ} \mathrm{C}$, kelembaban udara rata-rata antara $70-80 \%$. Menurut Surat Keputusan Menteri Kehutanan Nomor 75/Menhut-II/2004 Tanggal 11 Maret 2004. Hutan penelitian Riam Kiwa termasuk kedalam kawasan hutan produksi tetap seluas 1055 Ha dan 420 Ha termasuk hutan produksi yang dapat dikonversi.

Bahan-bahan yang dibutuhkan dalam penelitian ini adalah meliputi minyak bensin dan solar untuk pembakaran dan air untuk pemadaman. Sedangkan peralatan yang diperlukan meliputi alat-alat penyiangan seperti sabit dan parang, alat ukur yang terdiri dari meteran 2 meter, alat meteran 50 meter, counter, alat ukur tinggi api dan alat pemadam kepyok dan semprot punggung. Alat pembuat api yang digunakan adalah drip torches. Untuk mengukur bobot bahan bakar hasil tebasan penyiangan digunakan timbangan analitik. Kadar air bahan bakar tebasan akan diukur dengan oven pengering. Alat lain yang digunakan adalah kamera dan alat tulis. 


\section{B. Prosedur Kerja Penelitian}

Tanaman umur dua tahun dibersihkan dari bahan bakar potensial berupa biomassa hidup yang terdiri dari gulma. Semua gulma yang tumbuh di lantai hutan ditebas hingga tinggi tebasan maksimum $10 \mathrm{~cm}$ dengan menggunakan sabit. Untuk vegetasi berkayu yang cukup keras dibantu dengan parang. Penebasan dilakukan terhadap gulma di bawah empat jenis pohon hutan umur dua tahun dengan jarak tanam 3X3 meter yaitu A. mangium, A. crassicarpa, A. scholaris dan E. pellita. Selanjutnya penebasan ditentukan dengan frekuensi setiap 6 bulan (S1), setiap 5 bulan (S2), setiap 4 bulan (S3), setiap 3 bulan (S4) dan tanpa tebas (kontrol/S0). Jumlah tenaga kerja yang dikerjakan ditentukan berdasarkan pada luasan yang akan disiang dan waktu yang diperlukan. Tenaga kerja dipimpin oleh seorang mandor. Biomassa hasil penebasan dibiarkan terdekomposisi. Untuk hasil tebasan yang terlalu menumpuk disebar secara merata agar mempercepat proses dekomposisi dan merendahkan tinggi bahan bakar. Vegetasi yang memiliki banyak ranting, penebasannya dilakukan hingga volumenya menyusut sedemikian rupa dengan cara memangkas ranting. Petak ukur bahan bakar potensial diletakan pada lantai hutan keempat jenis pohon tersebut di atas dimana masing-masing petak ukur berukuran $1 \mathrm{~m}^{2}$. Dengan demikian didalam satu tegakan hutan ada 4 petak ukur yang diletakkan secara acak. Bahan bakar didalam setiap petak ukur ditimbang berat basahnya menggunakan timbangan analitik. Semua vegetasi gulma yang tumbuh disatukan sebagai bahan bakar potensial.Demikian juga kerapatan gulma diukur terhadap semua jenis gulma. Pengukuran tinggi gulma dilakukan pada setiap satu hari sebelum penebasan gulma dilakukan. Panjang hangus batang diukur dari pangkal akar hingga ujung tanda hangus bagian atas batang. Bahan bakar yang ada umumnya didominasi rumput alang-alang (Imperata cylindrica). Intensitas cahaya diukur dengan Light meter pada jam 12.00-13.00. Tinggi batang pohon diukur menggunakan galah ukur dengan batas pengukuran dari pangkal akar hingga pangkal pucuk. Diamater pohon diukur setinggi dada. Lebar tajuk diukur dua kali yaitu lebar terpanjang dan lebar terpendek kemudian di bagi dua. Pembakaran dilakukan pada Bulan September 2005, jam 12.00 WITA dengan cara membuat api pada gulma alang-alang di setiap tepi tegakan tanaman hutan menggunakan "drip torches" (penyulut api) berbahan bakar bensin dicampur solar. Dalam setiap jenis tegakan hutan, sample (petak ukur) disusun dengan rancangan acak kelompok atau blok (RCBD). Petak ukur sebagai satuan percobaan adalah segi empat berukuran $1 \mathrm{~m} 2$ dengan 5 taraf perlakuan seperti tersebut diatas. Setiap perlakuan diulang sebanyak 4 kali. Pengukuran pohon dilakukan dalam ukuran plot 6 X 9m (10 pohon).

\section{Analisa Data}

Data yang sifatnya kualitatif dianalisa secara deskriptif dengan pola tabulasi. Data kuantitatif dari hasil pengaruh perlakuan, dianalisa dengan analisis varian (ANOVA) sesuai rancangan percobaan acak berblok/kelompok.

Model matematika Rancangan Acak Kelompok (RCBD) adalah sebagai berikut (Gaspersz, 1991) :

Dimana :

$$
\mathbf{Y i j}=\mathbf{U}+\mathbf{T i}+\mathbf{B j}+\mathbf{E i j}
$$

Yij : Nilai pengamatan dari perlakuan ke-i dalam kelompok ke-j

U : Nilai tengah populasi

Ti : Pengaruh aditif dari perlakuan ke-I

Bj : Pengaruh aditif dari kelompok ke-j

Eij : Pengaruh galat percobaan dari perlakuan ke-i pada kelompok ke-j 
Tata waktu penelitian sebagaimana disajikan didalam Tabel 1.

Tabel (Table) 1. Jadwal waktu pelaksanaan penelitian pengaruh frekuensi pemeliharaan terhadap resiko kebakaran pada hutan tanaman (Time schedule of research activity)

\begin{tabular}{|c|c|c|c|c|c|c|c|c|c|c|c|c|c|}
\hline \multirow[t]{2}{*}{ No } & \multirow{2}{*}{$\begin{array}{c}\text { Jenis Kegiatan } \\
\text { (activity) }\end{array}$} & \multicolumn{12}{|c|}{ Bulan (month) } \\
\hline & & 1 & 2 & 3 & 4 & 5 & 6 & 7 & 8 & 9 & 10 & 11 & 12 \\
\hline 1. & $\begin{array}{l}\text { Orientasi dan penyiapan } \\
\text { bahan (orientation and site } \\
\text { preparation) }\end{array}$ & & & & & & & & & & & & \\
\hline \multirow[t]{5}{*}{2.} & $\begin{array}{l}\text { Penelitian/pengamatan } \\
\text { (observation\&treatment) }\end{array}$ & & & & & & & & & & & & \\
\hline & $\begin{array}{l}\text { Pemeliharaan I } \\
\text { (weeding S1) }\end{array}$ & & & & & & & & & & & & \\
\hline & $\begin{array}{l}\text { Pemeliharaan II } \\
\text { (weeding S2) }\end{array}$ & & & & & & & & & & & & \\
\hline & $\begin{array}{l}\text { Pemeliharaan III (weeding } \\
\text { S3) }\end{array}$ & & & & & & & & & & & & \\
\hline & $\begin{array}{l}\text { Pemeliharaan IV } \\
\text { (weeding S4) }\end{array}$ & & & & & & & & & & & & \\
\hline 3. & Analisa data (analysis) & & & & & & & & & & & & \\
\hline 4. & Pelaporan (reporting) & & & & & & & & & & & & \\
\hline
\end{tabular}

Catatan (Note) $\quad$ : Pengukuran 1 September 2005 (measured, September, $1^{\text {st }}, 2005$ ) Pembakaran 19 September 2005 (burned , September $19^{\text {th }}, 2005$ ).

Dalam menguji beda rata-rata variable digunakan Uji Tukey (Hanafiah, 1991)

[Tukey test is used to test the average means of variable (Hanafiah, 1991)]

\section{HASIL DAN PEMBAHASAN}

\section{A. Hasil}

\section{Pengaruh Penyiangan terhadap Resiko Kebakaran Jenis Acacia mangium}

Kondisi awal populasi alang-alang sebelum dipotong/ditebas menunjukkan bahwa pertumbuhan tinggi alang-alang yang tumbuh dibawah tegakan E. pellita dan A. scholaris lebih tinggi dibanding A. mangium dan A. crassicarpa (Tabel 2). Tingkat kerapatan alang-alang dibawah tegakan A. scholaris dan E. pellita lebih tinggi dari pada A. cacia mangium dan A. crassicarpa (Tabel 2).

Tabel (Table) 2. Kondisi alang-alang di bawah 4 jenis tanaman pohon hutan sebelum penyiangan (Initial condition of Imperata cylindrica under 4 plant species before weeding)

\begin{tabular}{|c|c|c|c|c|c|}
\hline \multirow{2}{*}{ No } & \multirow{2}{*}{$\begin{array}{l}\text { Parameter } \\
\text { (parameter) }\end{array}$} & \multicolumn{4}{|c|}{$\begin{array}{l}\text { Jenis Pohon Hutan pada Jarak Tanam } 3 \times 3 \\
\text { (tree species plantation in } 3 \times 3 \text { spacing) }\end{array}$} \\
\hline & & A. mangium & A. crassicarpa & A. scholaris & E. pellita \\
\hline 1 & $\begin{array}{l}\text { Tinggi gulma/weed height }(\mathrm{Cm}) \\
\text { Jumlah alang-alang /density of }\end{array}$ & 96.5 & 92.3 & 107.8 & 101.0 \\
\hline 2 & $\begin{array}{l}\text { Imperata (ind } / \mathrm{m}^{2} \text { ) } \\
\text { Bobot alang-alang/ Imperata }\end{array}$ & 29.0 & 28.5 & 42.5 & 46.0 \\
\hline 3 & & 252.5 & 151.3 & 351.5 & 365.0 \\
\hline
\end{tabular}


Tiga bulan sebelum Januari 2005, sebelumnya kondisi alang-alang telah diseragamkan yaitu disemprot dengan herbisida. Dengan demikian semua gulma memiliki kondisi awal sama. Setelah perlakuan penyiangan tebas total 3 bulan, 4 bulan, 5 bulan, 6 bulan dan tanpa disiang, gulma alangalang diukur sehingga kondisinya bervariasi diantara jenis. Hasil menunjukkan bahwa penyiangan tebas total berpengaruh sangat nyata terhadap tinggi, kerapatan dan berat basah gulma serta panjang hangus batang tanaman $A$. mangium setelah terbakar. Selanjutnya, hasil uji beda rata-rata diperoleh bahwa penyiangan setiap tiga bulan telah menghasilkan tinggi gulma terendah $(23 \mathrm{~cm})$ yang berbeda nyata dengan penyiangan setiap 4 bulan, 5 bulan, 6 bulan dan kontrol (tanpa penyiangan). Data selengkapnya disajikan dalam Tabel 3. Dari tabel nampak bahwa berat basah terendah juga diperoleh dari perlakuan penebasan setiap 3 bulan (99,5 gr) yang berbeda nyata dengan tebasan 5 bulan, 6 bulan dan kontrol, tetapi tidak berbeda nyata dengan tebasan 4 bulan.

Tingginya frekuensi penebasan ternyata telah menghasilkan kerapatan individu alang-alang meningkat. Sebagaimana dapat dilihat dalam Tabel 3, bahwa tebasan 3 dan 4 bulan menghasilkan kerapatan individu alang-alang tertinggi dibandingkan hasil tebasan 5 bulan dan 6 bulan. Sedangkan tebasan gulma 6 bulan tidak berbeda nyata dan tanpa tebas (kontrol). Setelah hutan terbakar ternyata tanaman A. mangium yang mengalami penebasan gulma tersering (setiap 3 bulan) menghasilkan panjang hangus batang terpendek yang berbeda nyata dengan tebasan 4 bulan, 5 bulan, 6 bulan dan kontrol. Gulma yang tidak mengalami penebasan telah menghasilkan panjang hangus batang tertinggi atau merusak tanaman.

Tabel (Table) 3. Hasil uji beda rata-rata pengaruh penyiangan gulma pada A. mangium ( Means test of weeds as effect of weeding of A. mangium)

\begin{tabular}{|c|c|c|c|c|}
\hline $\begin{array}{c}\text { Perlakuan Penyiangan } \\
\text { (weeding treatment) }\end{array}$ & $\begin{array}{c}\text { Tinggi Gulma } \\
\text { (weed } \\
\text { height)(Cm) }\end{array}$ & $\begin{array}{c}\text { Kerapatan gulma } \\
\text { (Weed density) } \\
\left(\text { Ind/ } \mathbf{m}^{2}\right)\end{array}$ & $\begin{array}{c}\text { Berat Basah } \\
\text { Gulma (fresh } \\
\text { weight) }\left(\mathbf{g r} / \mathbf{m}^{2}\right)\end{array}$ & $\begin{array}{c}\text { Panjang Hangus } \\
\text { Tanaman (length } \\
\text { of burned)(Cm) }\end{array}$ \\
\hline S0 & $167.5 e$ & $23.250 \mathrm{ab}$ & $327.50 \mathrm{c}$ & $305.00 \mathrm{e}$ \\
& $(6.45)$ & $(1.29)$ & $(17.08)$ & $(9.13)$ \\
S1 & $77.5 d$ & $22.250 \mathrm{a}$ & $180.50 \mathrm{~b}$ & $126.25 \mathrm{~d}$ \\
& $(6.45)$ & $(0.96)$ & $(4.20)$ & $(4.35)$ \\
S2 & $55.0 \mathrm{c}$ & $25.750 \mathrm{~b}$ & $141.75 \mathrm{ab}$ & $93.25 \mathrm{c}$ \\
& $(1.83)$ & $(1.71)$ & $(2.75)$ & $(2.99)$ \\
S3 & $41.75 \mathrm{~b}$ & $31.500 \mathrm{c}$ & $109.00 \mathrm{a}$ & $75.00 \mathrm{~b}$ \\
& $(1.71)$ & $(1.29)$ & $(2.94)$ & $(2.16)$ \\
S4 & $23.00 \mathrm{a}$ & $32.500 \mathrm{~cd}$ & $99.50 \mathrm{a}$ & $42.75 \mathrm{a}$ \\
& $(2.16)$ & $(1.73)$ & $(1.29)$ & $(2.25)$ \\
\hline
\end{tabular}

Keterangan : 1. Angka dengan huruf berbeda adalah berbeda nyata (Tukey's)

(remark) (numbers in the same letter are significant different (Tukey's)

2. Angka dalam kurung adalah simpangan baku

(numbers in parenthesis are standard deviation)
S0 = tanpa penyiangan

(without weeding)

S1 $=$ Penyiangan setiap 6 bln (weeding every 6 months)

S2 $=$ Penyiangan setiap 5 bln (weeding every 5 months)

S3 = Penyiangan setiap 4 bln (weeding every 4 months)

S4= Penyiangan setiap 3 bln (weeding every 3 months) 


\section{Pengaruh Penyiangan terhadap Resiko Kebakaran Jenis A. crassicarpa}

Frekuensi penyiangan tebas total berpengaruh nyata terhadap tinggi gulma bawah tegakan, kerapatan gulma dan berat basah gulma pada jenis A. crassicarpa. Disisi lain dampak pembakaran ternyata bervariasi akibat frekuensi penebasan berbeda terutama terhadap panjang hangus batang pohon A.crassicarpa setelah kebakaran. Tabel 4 memperlihatkan hasil uji lanjut dari anova dengan uji beda rata-rata prosedur Tukey. Dari tabel tersebut nampak bahwa penyiangan tebas total setiap 3 bulan menghasilkan tinggi gulma terendah $(30,5 \mathrm{~cm})$ yang berbeda nyata dengan tebasan setiap 4, 5, 6 bulan dan tanpa tebas. Gulma tanpa ditebas menghasilkan gulma tertinggi. Demikian pula yang terjadi pada berat basah gulma bawah tegakan, bahwa tebasan setiap 3 bulan ternyata menghasilkan berat basah gulma teringan (58 gr) yang berbeda nyata dengan tebasan 4, 5, 6 bulan dan kontrol. Namun demikian tingginya frekuensi penebasan ternyata telah meningkatkan jumlah individu alang-alang. Dari Tabel 4 dapat terlihat bahwa tebasan setiap 3 bulan menghasilkan kerapatan gulma tertinggi $(47,7 \mathrm{Ind} / \mathrm{m} 2)$ yang berbeda nyata dengan kerapatan gulma pada tebasan 4, 5, dan 6 bulan termasuk kontrol. Sedangkan gulma tanpa tebas (kontrol) menghasilkan kerapatan gulma rata-rata 21 Ind/m2.

Tabel (Table) 4. Hasil uji beda rata-rata pengaruh penyiangan gulma pada A. crassicarpa (means test of weeds as effect of weeding of A. ceassicarpa)

\begin{tabular}{|c|c|c|c|c|}
\hline \multirow{2}{*}{$\begin{array}{l}\text { Perlakuan Penyiangan } \\
\text { (weeding treatment) }\end{array}$} & \multicolumn{4}{|c|}{ Variabel (variable) } \\
\hline & $\begin{array}{l}\text { Tinggi Gulma } \\
\text { (weed height) } \\
\text { (Cm) }\end{array}$ & $\begin{array}{c}\text { Kerapatan Gulma } \\
\text { (weed } \\
\text { density)(Ind } / \mathbf{m}^{2} \text { ) }\end{array}$ & $\begin{array}{c}\text { Berat Basah } \\
\text { Gulma (fresh } \\
\text { weight) }\left(\mathrm{gr} / \mathrm{m}^{2}\right)\end{array}$ & $\begin{array}{l}\text { Panjang Hangus } \\
\text { Tanaman } \\
\text { (length of } \\
\text { burned) (Cm) }\end{array}$ \\
\hline S0 & $\begin{array}{c}162.50 e \\
(6.45)\end{array}$ & $\begin{array}{c}21.750 \mathrm{a} \\
(1.71)\end{array}$ & $\begin{array}{c}153.00 \mathrm{e} \\
(4.97)\end{array}$ & $\begin{array}{c}296.75 \mathrm{e} \\
(5.38)\end{array}$ \\
\hline S1 & $\begin{array}{l}88.50 d \\
(1.83)\end{array}$ & $\begin{array}{l}23.250 \mathrm{ab} \\
(1.71)\end{array}$ & $\begin{array}{l}136.75 \mathrm{~d} \\
(3.30)\end{array}$ & $\begin{array}{c}167.25 \mathrm{~d} \\
(3.10)\end{array}$ \\
\hline S2 & $\begin{array}{l}63.00 \mathrm{c} \\
(2.16)\end{array}$ & $\begin{array}{c}25.500 \mathrm{bc} \\
(1.29)\end{array}$ & $\begin{array}{c}107.25 \mathrm{c} \\
(2.22)\end{array}$ & $\begin{array}{c}123.25 \mathrm{c} \\
(2.75)\end{array}$ \\
\hline S3 & $\begin{array}{l}53.50 \mathrm{~b} \\
(2.89)\end{array}$ & $\begin{array}{c}30.500 \mathrm{c} \\
(1.29)\end{array}$ & $\begin{array}{l}74.00 \mathrm{~b} \\
(2.58)\end{array}$ & $\begin{array}{c}93.75 \mathrm{~b} \\
(2.63)\end{array}$ \\
\hline S4 & $\begin{array}{c}30.50 \mathrm{a} \\
(1.29)\end{array}$ & $\begin{array}{c}47.750 \mathrm{~d} \\
(1.71)\end{array}$ & $\begin{array}{l}58.00 \mathrm{a} \\
(2.16)\end{array}$ & $\begin{array}{c}60.50 \mathrm{a} \\
(1.29)\end{array}$ \\
\hline
\end{tabular}

Keterangan : 1. Angka dengan huruf berbeda adalah berbeda nyata (Tukey’s) (remark) (numbers in the same letter are significant different (Tukey's)

2. Angka dalam kurung adalah simpangan baku (numbers in parenthesis are standard deviation)

$\mathrm{S} 0=$ tanpa penyiangan (without weeding)

S1 = Penyiangan setiap 6 bln (weeding every 6 months)

S2 $=$ Penyiangan setiap 5 bln (weeding every 5 months)

S3 = Penyiangan setiap 4 bln (weeding every 4 months)

S4= Penyiangan setiap 3 bln (weeding every 3 months)

Efek dari pembakaran ternyata menghasilkan panjang hangus batang bervariasi dimana tebasan gulma 3 bulan menghasilkan panjang hangus batang terpendek yaitu hanya 60,5 cm, dimana nilai tersebut berbeda nyata dengan hasil tebasan 4 bulan, 5 bulan, 6 bulan dan kontrol. Suhu pembakaran yang terjadi adalah antara $600-700{ }^{\circ} \mathrm{C}$ dengan tinggi api antara $0,5-1$ meter. Kadar air bahan bakar antara $10-28 \%$. 


\section{Pengaruh Penyiangan terhadap Resiko Kebakaran Jenis Alstonia scholaris}

Seperti halnya pengaruh penyiangan terhadap resiko kebakaran $A$. mangium dan A. crassicarpa maka pada tanaman jenis $A$. scholaris terjadi pengaruh yang sama. Penyiangan berpengaruh sangat nyata terhadap tinggi dan kerapatan gulma bawah tegakan serta berat basah gulma pada tanaman A. scholaris. Setelah terjadi kebakaran, maka dampak kerusakannya dipengaruhi juga oleh perlakuan penyiangan tebas total sebelumnya. Penyiangan gulma setiap 3 bulan ternyata menghasilkan tinggi gulma terpendek $(38,5 \mathrm{~cm})$ yang berbeda nyata dengan penyiangan setiap 4 bulan, 5 bulan, 6 bulan dan tanpa penyiangan. Sedangkan siangan 6 bulan pada $A$. scholaris ternyata tidak berbeda nyata dengan kontrol (tanpa disiang).

Tingginya frekuensi penyiangan ternyata telah meningkatkan kerapatan gulma bawah tegakan A. scholaris dimana penyiangan setiap 3 bulan menghasilkan kerapatan gulma tertinggi yaitu 72,5 Ind/m2 yang berbeda nyata dengan penyiangan setiap 4 bulan, 5 bulan, 6 bulan dan tanpa penyiangan. Sedangkan tanaman tanpa disiang menghasilkan kerapatan gulma 22,5 Ind/m2 yang tidak berbeda nyata dengan disiang setiap 6 bulan (24,08 Ind/m2). Data selengkapnya disajikan dalam Tabel 5.

Tabel (Table) 5. Hasil uji beda rata-rata pengaruh penyiangan gulma pada Alstonia scholaris (means test of weeds as effect of weeding on Alstonia scholaris)

\begin{tabular}{|c|c|c|c|c|}
\hline \multirow{2}{*}{$\begin{array}{c}\text { Perlakuan } \\
\text { Penyiangan (weeding } \\
\text { treatment) }\end{array}$} & \multicolumn{4}{|c|}{ Variabel (variable) } \\
\hline & $\begin{array}{c}\text { Tinggi Gulma } \\
\text { (weed } \\
\text { height)(Cm) }\end{array}$ & $\begin{array}{c}\text { Kerapatan Gulma } \\
\text { (weed } \\
\text { density)(Ind//m²) }\end{array}$ & $\begin{array}{c}\text { Berat Basah } \\
\text { Gulma (weed } \\
\text { weight)(gr/m²) }\end{array}$ & $\begin{array}{c}\text { Panjang Hangus } \\
\text { Tanaman (length } \\
\text { of burned }) \mathrm{Cm} \text { ) }\end{array}$ \\
\hline S0 & $\begin{array}{c}151.25 e \\
(3.50)\end{array}$ & $\begin{array}{c}22.50 \mathrm{a} \\
(2.08)\end{array}$ & $\begin{array}{c}396.50 \mathrm{~d} \\
(5.07)\end{array}$ & $\begin{array}{c}295.50 \mathrm{e} \\
(3.42)\end{array}$ \\
\hline S1 & $\begin{array}{c}108.75 \mathrm{~cd} \\
(6.29)\end{array}$ & $\begin{array}{c}24.25 \mathrm{ab} \\
(1.71)\end{array}$ & $\begin{array}{c}385.00 \mathrm{~cd} \\
(12.91)\end{array}$ & $\begin{array}{c}223.75 \mathrm{~d} \\
(4.11)\end{array}$ \\
\hline S2 & $\begin{array}{l}92.50 \mathrm{c} \\
(2.08)\end{array}$ & $\begin{array}{l}39.50 \mathrm{~b} \\
(1.29)\end{array}$ & $\begin{array}{c}357.50 \mathrm{c} \\
(2.38)\end{array}$ & $\begin{array}{c}181.50 \mathrm{e} \\
(2.38)\end{array}$ \\
\hline S3 & $\begin{array}{c}62.75 \mathrm{~b} \\
(2.22)\end{array}$ & $\begin{array}{c}52.50 \mathrm{c} \\
(1.83)\end{array}$ & $\begin{array}{c}212.50 \mathrm{~b} \\
(3.51)\end{array}$ & $\begin{array}{c}117.75 \mathrm{~b} \\
(2.22)\end{array}$ \\
\hline S4 & $\begin{array}{c}38.50 \mathrm{a} \\
(1.29)\end{array}$ & $\begin{array}{l}72.50 \mathrm{~d} \\
(2.08)\end{array}$ & $\begin{array}{c}208.50 \mathrm{a} \\
(2.65)\end{array}$ & $\begin{array}{c}75.50 \mathrm{a} \\
(1.29)\end{array}$ \\
\hline
\end{tabular}

Keterangan : 1. Angka dengan huruf berbeda adalah berbeda nyata (Tukey's) (remark) (numbers in the same letter are significant different (Tukey's)

2. Angka dalam kurung adalah simpangan baku (numbers in parenthesis are standard deviation)

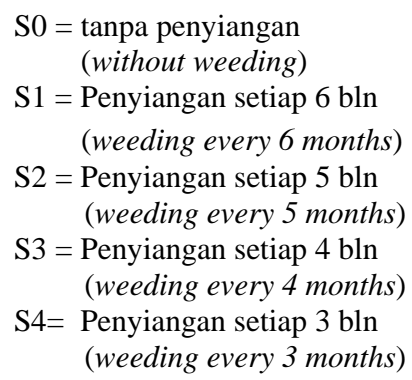

Dampak kebakaran menghasilkan panjang hangus batang terpendek pada hasil penyiangan setiap 3 bulan $(75,5 \mathrm{~cm})$ dan berbeda nyata dengan siangan 4 bulan, 5 bulan, 6 bulan dan kontrol. Tanaman A. scholaris tanpa disiang menghasilkan panjang hangus batang terpanjang $(295,5 \mathrm{~cm})$.

\section{Pengaruh Penyiangan terhadap Resiko Kebakaran Hutan Tanaman Jenis Eucalyptus pellita}

Hasil percobaan menunjukkan bahwa penyiangan sangat mempengaruhi rawan tidaknya kebakaran pada tanaman jenis E. pellita. Rawan tidaknya tanaman terhadap kebakaran diindikasikan oleh adanya variasi tinggi gulma, kerapatan gulma, berat basah gulma dan panjang hangus batang pasca kebakaran. Tabel 6 menunjukkan bahwa penyiangan setiap 3 bulan sekali menghasilkan tinggi 
gulma bawah tegakan E. pellita terendah $(43,5 \mathrm{~cm})$ yang tidak berbeda nyata dengan penyiangan 4 bulan, berbeda nyata dengan penyiangan 5 bulan, 6 bulan dan kontrol. Gulma tertinggi $(157,5 \mathrm{~cm})$ diperoleh dari tegakan tanaman tanpa disiang. Berat basah gulma teringan $(121,5$ gr) diperoleh pada penyiangan tiap 3 bulan yang berbeda nyata dengan penyiangan setiap 4 bulan, 5 bulan, 6 bulan dan tanpa disiang.

Tabel (Table) 6. Hasil uji beda rata-rata pengaruh penyiangan gulma pada Eucalyptus pellita (means test of weeds as effect of weeding of Eucalyptus pellita)

\begin{tabular}{|c|c|c|c|c|}
\hline \multirow{2}{*}{$\begin{array}{l}\text { Perlakuan Penyiangan } \\
\text { (weeding treatment) }\end{array}$} & \multicolumn{4}{|c|}{ Variabel (variable) } \\
\hline & $\begin{array}{c}\text { Tinggi Gulma } \\
\text { (weed } \\
\text { height)(Cm) }\end{array}$ & $\begin{array}{c}\text { Kerapatan Gulma } \\
\text { (weed } \\
\text { density)(Ind/m²) }\end{array}$ & $\begin{array}{c}\text { Berat Basah } \\
\text { Gulma (weed } \\
\text { weight)(gr/m²) }\end{array}$ & $\begin{array}{l}\text { Panjang Hangus } \\
\text { Tanaman (length } \\
\text { of burned) (Cm) }\end{array}$ \\
\hline S0 & $\begin{array}{c}157.50 e \\
(2.08)\end{array}$ & $\begin{array}{c}23.00 \mathrm{a} \\
(1.63)\end{array}$ & $\begin{array}{c}395.00 \text { de } \\
(9.13)\end{array}$ & $\begin{array}{l}249.5 \mathrm{e} \\
(2.65)\end{array}$ \\
\hline S1 & $\begin{array}{c}105.75 c d \\
(4.35)\end{array}$ & $\begin{array}{c}23.500 \mathrm{a} \\
(1.29)\end{array}$ & $\begin{array}{c}378.75 \mathrm{~d} \\
(8.54)\end{array}$ & $\begin{array}{l}196.5 \mathrm{~d} \\
(2.65)\end{array}$ \\
\hline S2 & $\begin{array}{l}94.50 \mathrm{c} \\
(1.29)\end{array}$ & $\begin{array}{c}49.750 \mathrm{~b} \\
(1.71)\end{array}$ & $\begin{array}{c}266.75 \text { e } \\
(5.38)\end{array}$ & $\begin{array}{c}172.00 \mathrm{c} \\
(2.16)\end{array}$ \\
\hline S3 & $\begin{array}{c}67.75 \mathrm{ab} \\
(2.22)\end{array}$ & $\begin{array}{c}72.750 \mathrm{~d} \\
(2.22)\end{array}$ & $\begin{array}{c}215.75 \mathrm{~b} \\
(4.35)\end{array}$ & $\begin{array}{c}137.00 \mathrm{~b} \\
(3.56)\end{array}$ \\
\hline S4 & $\begin{array}{c}43.50 \mathrm{a} \\
(1.29)\end{array}$ & $\begin{array}{c}83.500 \text { e } \\
(1.29)\end{array}$ & $\begin{array}{c}121.50 \mathrm{a} \\
(3.11)\end{array}$ & $\begin{array}{c}80.50 \mathrm{a} \\
(1.29)\end{array}$ \\
\hline
\end{tabular}

Keterangan : 1. Angka dengan huruf berbeda adalah berbeda nyata (Tukey's) (remark) (numbers in the same letter are significant different (Tukey's)

2. Angka dalam kurung adalah simpangan baku (numbers in parenthesis are standard deviation)
S0 = tanpa penyiangan (without weeding)

S1 $=$ Penyiangan setiap 6 bln (weeding every 6 months)

S2 = Penyiangan setiap 5 bln (weeding every 5 months)

S3 = Penyiangan setiap 4 bln (weeding every 4 months)

S4= Penyiangan setiap 3 bln (weeding every 3 months)

Tanaman tanpa disiang menghasilkan berat basah gulma terberat yaitu 395 gr. Penyiangan ternyata telah meningkatkan kerapatan gulma. Kondisi tersebut ditunjukkan oleh penyiangan tiap 3 bulan dimana menghasilkan kerapatan gulma tertinggi $(83,5 \mathrm{Ind} / \mathrm{m} 2)$ yang berbeda nyata dengan siangan 4, 5, 6 bulan dan tanpa siangan.

Penyiangan setiap 3 bulan juga telah menghasilkan panjang hangus batang terpendek $(80,5 \mathrm{~cm})$ yang berbeda nyata dengan penyiangan setiap 4 bulan, 5 bulan, 6 bulan dan tanpa disiang. Tanaman tanpa disiangi menghasilkan panjang hangus batang terpanjang $(249,5 \mathrm{~cm})$ yang dapat mematikan tanaman saat terjadi kebakaran.

\section{Pengaruh Penyiangan terhadap Pertumbuhan Tinggi dan Diameter Tajuk Tanaman}

Tingkat keseringan penyiangan tebas total selain berpengaruh terhadap kondisi gulma bawah tegakan hutan tanaman, ternyata berpengaruh juga terhadap pertumbuhan tanaman itu sendiri dalam satu tahun, kecuali terhadap diameter tajuk jenis A. scholaris dan E. pellita yang tidak berpengaruh nyata.

Hasil uji beda rata-rata (Tabel 7) menunjukkan bahwa penyiangan setiap 3 bulan menghasilkan ukuran batang $A$. mangium tertinggi $(7,97 \mathrm{~m})$ yang tidak berbeda nyata dengan penyiangan 4 bulan, berbeda nyata dengan penyiangan 5 bulan, 6 bulan dan kontrol. 
Tinggi batang A. mangium tanpa disiang adalah 7,2 m yang merupakan batang terpendek dibandingkan perlakuan lain. Demikian juga yang terjadi pada diameter tajuk bahwa penyiangan 3 bulan telah menghasilkan diameter tajuk terlebar (3,6 m) yang berbeda nyata dengan penyiangan 4 bulan, 5 bulan, 6 bulan dan tanpa penyiangan. Tanaman tidak disiang menghasilkan lebar tajuk tersempit (3,3 m) diantara semua perlakuan.

Penyiangan setiap 3 bulan juga telah menghasilkan pertumbuhan batang A. crassicarpa tertinggi $(8,9 \mathrm{~m})$ yang berbeda nyata dengan hasil siangan setiap 4 bulan, 5 bulan, 6 bulan dan kontrol. Sedangkan tanaman yang tidak disiang menghasilkan tinggi batang terendah $(8,0 \mathrm{~m})$ diantara perlakuan lain walaupun tidak berbeda nyata dengan penyiangan 6 bulan dan 5 bulan. Demikian pula pengaruh penyiangan setiap 3 bulan telah menghasilkan pertumbuhan diameter tajuk terlebar $(2,9 \mathrm{~m})$ yang berbeda nyata dengan penyiangan 4 bulan, 5 bulan, 6 bulan dan kontrol.

Seperti halnya terhadap 2 jenis terdahulu, penyiangan setiap 3 bulan terhadap A. scholaris telah menghasilkan batang tertinggi $(3,5 \mathrm{~cm})$ yang tidak berbeda nyata dengan hasil siangan 4 bulan, berbeda nyata dengan siangan 5 bulan, 6 bulan dan kontrol. Sedangkan perlakuan penyiangan ternyata tidak berpengaruh nyata terhadap pertumbuhan diameter tajuk.

Tabel (Table) 7. Pengaruh penyiangan terhadap pertumbuhan tinggi dan diameter tajuk tanaman (The influence of weeding on heigth and crown diameter growth)

\begin{tabular}{|c|c|c|c|c|c|c|}
\hline \multirow{2}{*}{$\begin{array}{c}\text { Jenis Tanaman } \\
\text { (species) }\end{array}$} & \multirow[t]{2}{*}{ Parameter } & \multicolumn{5}{|c|}{ Frekuensi Penyiangan (weeding frequency) } \\
\hline & & So & S1 & S2 & S3 & S4 \\
\hline \multirow[t]{2}{*}{ Acacia mangium } & Tinggi & $\begin{array}{l}7.250 \mathrm{a} \\
(0.13)\end{array}$ & $\begin{array}{l}7.300 \mathrm{ab} \\
(0.18)\end{array}$ & $\begin{array}{l}7.350 \mathrm{ab} \\
(0.25)\end{array}$ & $\begin{array}{l}7.475 \mathrm{bc} \\
(0.25)\end{array}$ & $\begin{array}{l}7.975 \mathrm{c} \\
(0.51)\end{array}$ \\
\hline & $\begin{array}{l}\text { Diamater } \\
\text { Tajuk }\end{array}$ & $\begin{array}{l}3.3500 \mathrm{bc} \\
(0.23)\end{array}$ & $\begin{array}{l}3.1250 \text { a } \\
(0.09)\end{array}$ & $\begin{array}{l}3.2500 \mathrm{ab} \\
(0.13)\end{array}$ & $\begin{array}{l}3.3250 \mathrm{~b} \\
(0.17)\end{array}$ & $\begin{array}{l}3.5500 \mathrm{c} \\
(0.13)\end{array}$ \\
\hline \multirow[t]{2}{*}{ Acacia crassicarpa } & Tinggi & $\begin{array}{l}7.9750 \mathrm{a} \\
(0.22)\end{array}$ & $\begin{array}{l}8.0000 \mathrm{a} \\
(0.37)\end{array}$ & $\begin{array}{l}8.0000 \mathrm{a} \\
(0.08)\end{array}$ & $\begin{array}{l}8.3000 \mathrm{ab} \\
(0.18)\end{array}$ & $\begin{array}{l}8.9250 \mathrm{~b} \\
(0.31)\end{array}$ \\
\hline & $\begin{array}{l}\text { Diameter } \\
\text { Tajuk }\end{array}$ & $\begin{array}{l}1.7500 \mathrm{a} \\
(0.13)\end{array}$ & $\begin{array}{l}1.6250 \mathrm{a} \\
(0.22)\end{array}$ & $\begin{array}{r}2.4500 \mathrm{~b} \\
(0.13) \\
\end{array}$ & $\begin{array}{l}2.4500 \mathrm{~b} \\
(0.13)\end{array}$ & $\begin{array}{l}2.9500 \mathrm{c} \\
(0.13)\end{array}$ \\
\hline \multirow[t]{2}{*}{ Alstonia scholaris } & Tinggi & $\begin{array}{l}3.0250 \mathrm{ab} \\
(0.17)\end{array}$ & $\begin{array}{l}2.9500 \text { a } \\
(0.13)\end{array}$ & $\begin{array}{l}3.1250 \mathrm{~b} \\
(0.17)\end{array}$ & $\begin{array}{l}3.1250 \mathrm{bc} \\
(0.25)\end{array}$ & $\begin{array}{l}3.5000 \mathrm{c} \\
(0.22)\end{array}$ \\
\hline & $\begin{array}{l}\text { Diameter } \\
\text { Tajuk }\end{array}$ & \multicolumn{5}{|c|}{$\begin{array}{l}\text { Tidak berpengaruh nyata } \\
\text { (not significant different) }\end{array}$} \\
\hline \multirow[t]{2}{*}{ Eucalyptus pellita } & Tinggi & $\begin{array}{l}2.7500 \mathrm{ab} \\
(0.13)\end{array}$ & $\begin{array}{l}2.7500 \mathrm{ab} \\
(0.16)\end{array}$ & $\begin{array}{l}2.6750 \mathrm{a} \\
(0.69)\end{array}$ & $\begin{array}{l}3.5500 \mathrm{~b} \\
(0.29) \\
\end{array}$ & $\begin{array}{l}3.7000 \mathrm{c} \\
(0.16)\end{array}$ \\
\hline & $\begin{array}{l}\text { Diameter } \\
\text { Tajuk }\end{array}$ & \multicolumn{5}{|c|}{$\begin{array}{l}\text { Tidak berpengaruh nyata } \\
\text { (not significant different) }\end{array}$} \\
\hline
\end{tabular}

Keterangan : 1. Angka dengan huruf berbeda adalah berbeda nyata (Tukey's) (remark) (numbers in the same letter are significant different (Tukey's)
2. Angka dalam kurung adalah simpangan baku (numbers in parenthesis are standard deviation)

$$
\begin{aligned}
\mathrm{S} 0= & \text { tanpa penyiangan } \\
& \text { (without weeding) } \\
\mathrm{S} 1= & \text { Penyiangan setiap } 6 \mathrm{bln} \\
& \quad \text { (weeding every } 6 \text { months) } \\
\mathrm{S} 2= & \text { Penyiangan setiap } 5 \mathrm{bln} \\
& \quad \text { (weeding every } 5 \text { months) } \\
\mathrm{S} 3= & \text { Penyiangan setiap } 4 \mathrm{bln} \\
& \quad \text { (weeding every } 4 \text { months) } \\
\mathrm{S} 4= & \text { Penyiangan setiap } 3 \text { bln } \\
& \text { (weeding every } 3 \text { months) }
\end{aligned}
$$

Penyiangan tebas total juga berpengaruh nyata terhadap pertumbuhan tinggi E. pellita dimana perlakuan penyiangan setiap 3 bulan menghasilkan batang tertinggi $(3,7 \mathrm{~m})$ yang berbeda nyata dengan hasil siangan setiap 4 bulan, 5 bulan, 6 bulan dan kontrol (tanpa disiang). Disisi lain ternyata penyiangan tidak berpengaruh nyata terhadap pertumbuhan diameter tajuk. Tanaman E. pellita tanpa disiang menghasilkan pertumbuhan tinggi terendah $(2,7 \mathrm{~m})$ dibanding perlakuan lainnya. 


\section{Pengaruh Penyiangan terhadap Ketahanan Hidup Jenis Pohon Hutan akibat Kebakaran}

Penyiangan ternyata berpengaruh nyata terhadap ketahanan hidup tanaman hutan saat pasca kebakaran (Tabel 8 dan Tabel 9).

Tabel (Table ) 8. Persentase ketahanan hidup tanaman pohon hutan akibat kebakaran (Survival rate of tree species after burning)

\begin{tabular}{|c|c|c|c|c|c|c|}
\hline \multirow[t]{2}{*}{ No } & \multirow[t]{2}{*}{$\begin{array}{l}\text { Jenis/Blok } \\
\text { (species) }\end{array}$} & \multicolumn{5}{|c|}{$\begin{array}{l}\text { Persentase Hidup setelah Penebasan } \\
\text { (survival rate after weeding) }\end{array}$} \\
\hline & & S1 & S2 & S3 & S4 & So \\
\hline 1 & A. mangium & 100 (HBD) & $\begin{array}{l}100(\mathrm{HB}) \\
100(\mathrm{HB})\end{array}$ & 100 & 100 & $\begin{array}{l}80 \text { (HBD) } \\
70 \text { (HBD) }\end{array}$ \\
\hline 2 & A. crassicarpa & 100 (HBD) & $\begin{array}{l}100(\mathrm{HB}) \\
100(\mathrm{HB})\end{array}$ & 100 & 100 & $\begin{array}{l}80 \text { (HBD) } \\
70 \text { (HBD) }\end{array}$ \\
\hline 3 & A. scholaris & 100 (HBD) & & 100 & 100 & \\
\hline 4 & E. pellita & 100 (HBD) & & 100 & 100 & \\
\hline
\end{tabular}

Keterangan (remark) : HB = Hangus batang (burned stem), HBD = Hangus batang \& dahan (burned stem \& branch)

Semua jenis yang mengalami penyiangan setiap 3 bulan, 4 bulan, 5 bulan, 6 bulan menghasilkan ketahanan hidup $100 \%$ pasca terjadinya pembakaran (Tabel 7) sedangkan tanaman yang tidak mengalami pemeliharaan mengalami kematian $25 \%$ setelah terbakar.

Tabel (Table) 9. Pengaruh penyiangan gulma terhadap ketahanan kebakaran tanaman Acacia crassicarpa (The influence of weeding on the survival rate of A. crassicarpa)

\begin{tabular}{|c|c|c|c|c|c|}
\hline $\begin{array}{c}\text { Sumber variasi } \\
\text { (source of variation) }\end{array}$ & DF & SS & MS & $\mathbf{F}$ & $\mathbf{P}$ \\
\hline $\begin{array}{l}\text { Penyiangan (weeding) } \\
\text { Error } \\
\text { Total }\end{array}$ & $\begin{array}{l}4 \\
15 \\
19\end{array}$ & $\begin{array}{l}2000,50 \\
100,00 \\
2100,00\end{array}$ & $\begin{array}{l}500,00 \\
6,67\end{array}$ & 75,00 & 0,00 \\
\hline \multicolumn{6}{|c|}{ Uji Beda Rata-rata (Tukey) / means test (Tukey) } \\
\hline & $\begin{array}{l}\text { S4 } \\
100,00 \\
(0,00) \\
\text { a }\end{array}$ & $\begin{array}{l}\text { S3 } \\
100,00 \\
(0,00) \\
a\end{array}$ & $\begin{array}{l}\text { S2 } \\
100,00 \\
(0,00) \\
a\end{array}$ & $\begin{array}{l}\text { S1 } \\
100,50 \\
(0,00) \\
a\end{array}$ & $\begin{array}{l}\text { S0 } \\
75,00 \\
(5,77) \\
\text { b }\end{array}$ \\
\hline
\end{tabular}

Hasil uji beda rata-rata (Tabel 9) menunjukkan bahwa perlakuan penyiangan dari mulai setiap 3 bulan, 4 bulan, 5 bulan dan 6 bulan tidak berbeda nyata, tetapi keempat perlakuan tersebut berbeda nyata dengan tanpa disiang yang menghasilkan ketahanan hidup 75\%.

\section{Kondisi Intensitas Cahaya pada 4 Jenis Pohon Hutan}

Walaupun tidak diuji pengaruh jenis terhadap penetrasi cahaya yang masuk kedalam tegakan, nampak bahwa intensitas cahaya yang tembus ke lantai tegakan yang bervariasi dimana ada kecendrungan bahwa cahaya yang masuk ke tegakan tanaman $A$. scholaris menempati urutan tertinggi (73090 lux) diikuti oleh tanaman E. pellita dan A. crassicarpa, Sedangkan tanaman A. mangium memiliki penetrasi cahaya terendah (19800 lux). Data selengkapnya disajikan pada Tabel 10. 
Tabel (Table)10. Penetrasi cahaya yang masuk kesetiap tegakan hutan tanaman (lux) (light penetration inside the forest stand/lux)

\begin{tabular}{|c|l|c|c|}
\hline No & \multicolumn{1}{|c|}{$\begin{array}{c}\text { Jenis Tanaman } \\
\text { (species) }\end{array}$} & $\begin{array}{c}\text { Jumlah ulangan } \\
\text { (replication) }\end{array}$ & $\begin{array}{c}\text { Intensitas cahaya rata-rata } \\
\text { (mean of light intensity) (Lux) }\end{array}$ \\
\hline 1 & A. mangium & 10 & $19800 \pm 4168,7$ \\
\hline 2 & A. crassicarpa & 10 & $39240 \pm 3036,5$ \\
\hline 3 & A. scholaris & 10 & $73090 \pm 1801,5$ \\
\hline 4 & E. pellita & 10 & $67960 \pm 1732,8$ \\
\hline
\end{tabular}

\section{Pertumbuhan 4 Jenis Tanaman Model}

Hasil pertumbuhan 4 jenis pohon hutan tanaman yang diuji hingga umur 2 tahun disajikan dalam Tabel 11. Dari data pada tabel nampak bahwa telah terjadi proses pertumbuhan tanaman yang diindikasikan oleh pertumbuhan ukuran tinggi dan diameter batang serta ukuran lebar tajuk (Tabel 11).

Jenis $A$. crassicarpa mengalami peningkatan tinggi batang 190\%, diameter batang $150 \%$ dan lebar tajuk 88\% pada umur 2 tahun. Jenis A. mangium mengalami pertambahan tinggi batang 228\%, diameter batang $182 \%$ dan lebar tajuk 133\% pada umur 2 tahun. Jenis A. scholaris mengalami peningkatan ukuran tinggi tanaman 194\%, diameter batang 72\% dan lebar tajuk 86\% pada umur 2 tahun. Jenis E. pellita pada umur 2 tahun mengalami peningkatan ukuran tinggi tanaman $160 \%$, diameter batang 54\% dan lebar tajuk 107\%.

Tabel (Table) 11. Pertumbuhan jenis pohon model hutan tanaman beresiko rendah kebakaran (tree species growth of low fire risk plantation)

\begin{tabular}{|c|c|c|c|c|c|c|c|}
\hline \multirow[t]{2}{*}{ No } & \multirow{2}{*}{$\begin{array}{c}\text { Jenis } \\
\text { (species) }\end{array}$} & \multicolumn{3}{|c|}{ Umur 12 bulan (12 month old) } & \multicolumn{3}{|c|}{ Umur 24 bulan (24 month old) } \\
\hline & & $T(\mathrm{~m})$ & D (mm) & LT (m) & $\mathbf{T}(\mathbf{m})$ & D (mm) & LT (m) \\
\hline 1 & A. crassicarpa & 275,1 & $\begin{array}{l}32,9 \\
(1,77)\end{array}$ & 102,2 & 880,2 & 87,2 & 192,0 \\
\hline & & $(6,7)$ & $(1,77)$ & $(3,2)$ & $(85,4)$ & $(7,8)$ & $(49,7)$ \\
\hline 2 & A. mangium & 264,5 & 35,8 & 148,8 & 868,0 & 101,0 & 347,0 \\
\hline & & $(0,9)$ & $(0,8)$ & $(5,5)$ & $(34,2)$ & $(12,7)$ & $(45,6)$ \\
\hline 3 & A. scholaris & 121,5 & 26,4 & 98,1 & 357,4 & 45,4 & $\begin{array}{l}182,0 \\
(615)\end{array}$ \\
\hline & & $(6,4)$ & $(2,3)$ & $(6,6)$ & $(65,7)$ & $(16,1)$ & $(61,5)$ \\
\hline 4 & E. pellita & $\begin{array}{l}114,9 \\
(11,70\end{array}$ & $\begin{array}{l}18,8 \\
(0,8)\end{array}$ & $\begin{array}{l}71,3 \\
(48)\end{array}$ & 298,8 & 29,0 & $\begin{array}{l}148,0 \\
\left(22_{0}\right.\end{array}$ \\
\hline
\end{tabular}

Keterangan : - Angka didalam kurung adalah simpang baku

(remark) (numbers in parenthesis are standard deviation)

- T= tinggi / height, $\mathrm{D}=$ diameter / diameter, $\mathrm{LT}=$ lebar tajuk / canopy wide

\section{Kebutuhan Biaya Penyiangan}

Dari hasil pengujian 4 jenis penyiangan dengan tebas total gulma bawah tegakan diperoleh hasil rata-rata Hari Orang Kerja (HOK) 11,2 HOK untuk 4 jenis pohon yang diuji (Tabel 12). Pada penebasan pertama dan kedua dimana kondisi gulma cukup tinggi maka kemampuan kerja buruh adalah 12 HOK sedangkan setelah penebasan beberapa kali telah terjadi penurunan HOK menjadi 10 HOK. Dengan demikian rata-ratanya adalah 11 HOK. 
Tabel (Table) 12. Kemampuan tenaga kerja dalam penyiangan tebas total (menpower capacity in weeding)

\begin{tabular}{|c|l|c|c|c|}
\hline No & \multicolumn{1}{|c|}{$\begin{array}{c}\text { Aktivitas } \\
\text { (activity) }\end{array}$} & $\begin{array}{c}\text { HOK } \\
\text { (menpower) }\end{array}$ & $\begin{array}{c}\text { Biaya per HOK } \\
\text { (budget) }\end{array}$ & $\begin{array}{c}\text { Bahan dan alat } \\
\text { (material \& equipment) }\end{array}$ \\
\hline \multirow{2}{*}{1} & Tebas total / total weeding I (S1) & 12 & $20.000,-$ & \\
2 & Tebas total / total weeding II (S2) & 12 & $20.000,-$ & Arit, parang, asahan dan \\
3 & Tebas total / total weeding III (S3) & 11 & $20.000,-$ & konsumsi \\
4 & Tebas total / total weeding IV (S4) & 10 & $20.000,-$ & \\
\hline \multicolumn{2}{|l}{ Rata-rata (mean) } & 11,2 & & \\
\hline
\end{tabular}

\section{B. Pembahasan}

Dari 4 parameter utama pohon pada model hutan tanaman beresiko rendah kebakaran nampak bahwa penyiangan manual dengan cara tebas total telah menurunkan resiko kebakaran pada tanaman, semakin sering tanaman dipelihara maka nilai indikator-indikator bahaya kebakaran seperti tinggi gulma bawah tegakan, berat basah gulma dan panjang hangus batang akan semakin kecil baik pada jenis A. mangium, A. crassicarpa dan A. scholaris maupun pada E. pellita.

Terjadinya peningkatan kerapatan individu gulma akibat penebasan akan berhubungan dengan lamanya pembakaran bahan bakar. Sedangkan pada kondisi bahan bakar rapat tetapi pendek, api tidak akan menghasilkan panjang hangus batang yang tinggi sehingga tidak akan menganggu pertumbuhan tanaman secara serius. Peningkatan kerapatan individu gulma alang-alang (Imperata cylindrica) pada 4 jenis tanaman hutan berhubungan dengan adanya pemunculan tunas baru atau tumbuhnya kecambah benih alang-alang akibat terbuka oleh tebasan.

Variasi kondisi gulma alang-alang saat sebelum penebasan pada 4 jenis tanaman pohon hutan (Tabel 2) salah satunya adalah akibat adanya perbedaan penetrasi cahaya yang masuk kesetiap komunitas tanaman. Cahaya yang masuk ketegakan jenis A. mangium ternyata lebih kecil dibandingkan dengan yang masuk ke A. scholaris dan E. pellita (Tabel 10). Beberapa hasil penelitian menyimpulkan bahwa kecepatan tumbuh alang-alang berkurang pada intensitas cahaya yang rendah.

Berat basah gulma yang semakin ringan dari empat jenis tanaman hutan akibat tingginya frekuensi penebasan sangat berhubungan dengan proses dekomposisi biomass akibat tebasan. Pada penyiangan tebas total yang sering hasil tebasan rumput akan semakin banyak dan memiliki waktu dekomposisi lebih lama dibanding frekuensi penebasan yang lebih rendah. Sedangkan di dalam proses dekomposisi, kandungan air biomass beserta senyawa-senyawa kimia yang ada didalam biomass akan berkurang seiring dengan lamanya waktu. Sebagai bagian akhir dari proses dekomposisi adalah adanya penambahan unsur hara pada tanah dan bahan organik tanah. Namun demikian menurut Sastrawijaya (1991) proses dekomposisi dipengaruhi juga oleh adanya mikroba dekomposer tanah seperti jamur dan bakteri. Jika dihubungkan dengan bahaya atau resiko kebakaran maka tinggi gulma sangat berhubungan dengan tinggi api yang akan terjadi saat kebakaran. Data dari Tabel 2, 3, 4 dan 5 menunjukkan bahwa pada 4 jenis tanaman yaitu A. mangium, A. crassicarpa, A. scholaris dan E. pellita panjang hangus batang sangat ditentukan oleh tinggi gulma saat terbakar, tinggi rendahnya panjang hangus batang akan berpengaruh terhadap kelangsungan pertumbuhan tanaman bahkan dapat menyebabkan tanaman cacat hingga mengalami kematian. Pohon yang mengalami hangus batang yang panjang, sekalipun ia tetap tumbuh tetapi dapat merangsang pertumbuhan tunas baru pada bagian bawah dan kondisi tersebut dapat merusak kualitas batang. Untuk itu untuk mencegah terjadinya kerusakan yang parah, tanaman pohon hutan akan baik jika gulmanya diminimasi dengan cara penebasan total sesering mungkin. Menurut Brown \& Davis (1973), intensitas kebakaran (I) adalah 
sebanding dengan muatan bahan bakar (W) (ton/ha), panas spesifik bahan bakar $(\mathrm{H})(\mathrm{Kj} / \mathrm{Kg})$ dan kecepatan penjalaran api (r) (m/menit).

Hasil percobaan menunjukkan bahwa dari 4 jenis tanaman uji, maka penebasan gulma bawah tegakan setiap 3 bulan telah menghasilkan panjang hangus batang terpendek. Disisi lain, penebasan gulma setiap 3 bulan telah meningkatkan laju pertumbuhan tanaman.

Diameter tajuk tanaman hutan ternyata tidak selalu dipengaruhi oleh perlakuan penyiangan, seperti pada jenis tanaman A. scholaris dan E. pellita. Kondisi tersebut diduga akibat karakteristik jenis yang khas karena 2 jenis ini memiliki kecepatan tumbuh lebih rendah dibandingkan dengan A. mangium dan A. crassicarpa.

Walaupun didalam penelitian ini, pengamatan tidak sampai ke proses pemulihan kerusakan batang pohon akibat hangus terbakar, namun dengan menggunakan indikator tunas baru dan kondisi daun segar, dapat diperoleh bahwa penyiangan sangat berpengaruh terhadap ketahanan hidup jenis pohon hutan, tetapi selang waktu penyiangan setiap 3 bulan, 4 bulan, 5 bulan dan 6 bulan tidak menghasilkan perbedaan yang nyata dari empat jenis tanaman. Dengan menggunakan jenis sebagai blok/replikasi nampak bahwa tanaman hutan yang sama sekali tidak disiang mengalami kematian sekitar 25\%, dengan kata lain masih hidup 75\% dari total tanaman hutan yang ditanam. Kematian ditandai dengan akar kering dan dari batang tidak keluar tunas.

Penyiangan dengan tebas total merupakan salah satu cara penyiangan praktis dan pengerjaannya sudah dikenal oleh masyarakat sekitar hutan. Tetapi sebagian orang berpendapat bahwa penyiangan cara tersebut tidak efesien. Untuk memperoleh gambaran bahwa penyiangan akan merugikan atau menguntungkan dalam mengusahakan hutan tanaman, harus terlebih dahulu diketahui pendapatan yang akan diperoleh dari produksi kayu dalam suatu hutan tanaman. Nilai ekonomi satu jenis akan berbeda dengan jenis lainnya.

Pada Tabel 11 digambarkan bahwa dalam pelaksanaan penebasan 1 ha tanaman diperlukan rata-rata $11 \mathrm{HOK}$. Jika penebasan total dilakukan 4 kali dalam setahun berarti dalam 1 ha diperlukan 44 HOK dalam setahun. Sedangkan menurut pengalaman di Riam Kiwa untuk melakukan semprotan herbisida diperlukan 13 HOK (Temmes, 1992) Per ha. Hasil penelitian Akbar (2002) menunjukkan bahwa pertumbuhan kembali alang-alang akibat herbisida setelah 4 bulan adalah 6,5 cm. Kita anggap setiap 6 bulan alang-alang harus segera diherbisida lagi. Berarti dalam 1 tahun diperlukan 26 HOK ditambah 14 liter herbisida Round-up, jika harga Round-up Rp.50.000/ltr maka untuk 14 liter Roundup diperlukan biaya 14 X Rp. 50.000,- = Rp. 700.000,-/ha. Selama ini telah menjadi ketentuan bahwa dalam 1 ha lahan alang-alang diperlukan 7 liter herbisida round-up.

Biaya 1 HOK pada saat penelitian adalah Rp. 20.000,- sehingga untuk tebas total 1 ha dengan 4 kali penebasan gulma dibutuhkan biaya 44 X Rp. $20.000=$ Rp. 880.000,- sedangkan untuk penyiangan dengan herbisida dibutuhkan biaya 26 X Rp. 20.000,- = Rp. 520.000,- ditambah herbisida Rp. 700.000,- sehingga jumlahnya adalah Rp. 1.220.000,-/ha. Disini nampak sebenarnya penyiangan dengan tebas total lebih murah daripada dengan herbisida. Contoh yang mudah dilihat untuk tanaman pohon yang beresiko kecil kebakaran adalah kebun karet (Hevea braziliensis) pada perusahaan perseroan terbatas perkebunan karet di Indonesia. Pada areal perkebunan karet ( $\mathrm{H}$. braziliensis) hampir tidak pernah terjadi kebakaran serius atau terjadi intensitas kebakaran yang tinggi. kebakaran hanya terjadi pada serasah dan pendek sehingga hampir tidak ada pengaruh kepertumbuhan tanaman. Kondisi resiko kebakaran yang rendah tersebut adalah akibat pemeliharaan intensif yang dilakukan oleh perusahaan baik melalui penebasan maupun penyemprotan herbisida terhadap gulma. Sedangkan gulma utama yang umumnya dominan pada lahan bertanaman tahunan adalah alang-alang (Imperata cylindrica) (Barus, 2003). 
Keempat jenis pohon hutan tanaman telah menunjukkan bahwa peranan pemeliharaan sangat penting untuk menghindari kematian tanaman dimusim kering. Kebakaran yang terjadi biasanya berawal dari salah satu ladang diluar areal hutan tanaman. Kebakaran juga dapat berawal dari adanya api liar dari aktivitas pembakaran melalui puntung rokok, pemancingan, peremajaan rumput, perburuan, pertambangan dan pembakaran sampah rumah tangga serta sampah pertanian. Api yang datang dari luar tidak akan menjadi besar jika gulma cukup rendah apalagi jarang. Sebaliknya jika kondisi gulma cukup tinggi dan rapat maka kebakaran sedang sampai besar akan terjadi.

Salah satu parameter yang juga mempengaruhi ketahanan hidup suatu jenis pohon adalah tebal kulit batang. Semakin tebal kulit batang pohon cendrung semakin tahan pohon tersebut terhadap kebakaran. Sebagai contoh jenis yang tergolong tahan terhadap kebakaran di Riam Kiwa adalah Gmelina arborea dan Eucalyptus alba.

Terjadinya peningkatan pertumbuhan tanaman akibat pemeliharaan tebas total diduga akibat proses dekomposisi gulma menjadi bahan organik dan pencahayaan matahari yang lebih optimal daripada tanaman yang rapat dengan gulma. Pada gulma yang pendek akibat selalu dipotong telah menurunkan persaingan unsur hara antara tanaman dengan gulma karena pertumbuhan gulma telah diganggu oleh penebasan.

Hasil pengukuran tanaman pada umur 1 tahun dan 2 tahun (Tabel 11) menunjukkan bahwa karakteristik kecepatan tumbuh dari 4 jenis yang diuji berbeda. A. mangium dan A. crassicarpa nampak tumbuh lebih cepat dibandingkan jenis $A$. scholaris dan E. pellita. Hal tersebut berhubungan dengan kemampuan jenis dalam menghambat pertumbuhan alang-alang. Tanaman yang lebih cepat meninggi akan menghasilkan lebar tajuk yang lebih cepat menutup sehingga penetrasi cahaya perangsang tumbuh alang-alang akan semakin berkurang.

Bahan bakar merupakan komponen mutlak dalam proses terjadinya api (Brown \& Davis, 1973). Dalam hutan tanaman, tinggi rendahnya gulma akan menentukan tinggi dan intensitas api saat terjadi pembakaran, menurut Sagala (1992), tinggi api pada alang-alang akan mencapai 2 kali tinggi bahan bakarnya. Bahan bakar yang berukuran lebih kecil akan lebih mudah terbakar dibanding ukuran besar (Brown \& Davis, 1973). Kandungan kimia bahan bakar juga menentukan reaktivitas bahan bakar terhadap pemanasan (Wibowo, 1997).

Dalam mengelola bahan bakar lantai hutan tanaman ada tiga cara : (1) mengurangi bahan bakar, (2) menyekat bahan bakar dan (3) menghilangkan bahan bakar (Akbar, 1999).

\section{KESIMPULAN DAN SARAN}

\section{A. Kesimpulan}

1. Intensitas penyiangan dalam pengelolaan hutan tanaman sangat berpengaruh terhadap tingkat resiko kebakaran yang dapat mematikan tanaman pokok

2. Kecenderungan yang terjadi adalah bahwa semakin intensif penyiangan maka akan semakin rendah resiko kebakaran yang akan timbul

3. Penyiangan setiap 3 bulan dengan cara tebas total gulma bawah hutan tanaman telah menghasilkan tinggi gulma terpendek, berat basah gulma teringan dan panjang hangus batang pohon terendah akibat kebakaran. Sedangkan penyiangan telah meningkatkan kerapatan gulma bawah tegakan hutan. 
4. Intensitas penyiangan mempengaruhi pertumbuhan tinggi dan diameter tajuk pohon hutan tanaman jenis A. mangium dan A. crassicarpa tetapi tidak berpengaruh nyata pada diameter tajuk jenis A. scholaris dan E. pellita.

5. Empat jenis tanaman uji yang terdiri dari A. mangium, A. crassicarpa, E. pellita dan A. scholaris memiliki karakter tajuk berbeda sehingga menghasilkan penetrasi cahaya difusi berbeda yang dapat menciptakan kondisi gulma bawah tegakan berbeda pula.

6. Tanaman terpelihara telah menghasilkan daya tahan hidup lebih tinggi daripada tidak dipelihara saat kejadian kebakaran walaupun batang pohon mengalami hangus kulit batang.

\section{B. Saran}

Aplikasi pemeliharaan penyiangan setiap 3 bulan disarankan untuk mengurangi resiko kebakaran pada hutan tanaman dan meningkatkan laju pertumbuhan tanaman.

\section{DAFTAR PUSTAKA}

Akbar. 1999. Api Hutan dan Strategi Pemadamannya. Majalah Kehutanan Indonesia. Dephut. Jakarta.

Akbar. 2002. Teknologi dan Kelembagaan Pengendalian Kebakaran Hutan. Model Hutan Tanaman Beresiko Kecil Kebakaran. Pengaruh Pemeliharaan terhadap Penurunan Resiko Kebakaran pada Hutan Tanaman. Laporan BP2HT-IBT. Banjarbaru.

Barus, E. 2003. Pengendalian Gulma di Perkebunan. Efektifitas dan Efisiensi Aplikasi Herbisida, Kanisius. Yogyakarta. 103 Hal.

Brown A.A. dan K.P. Davis. 1973. Forest Fire Control and Use. Mc. Graw Hill and Book Co. New York).

Gaspers Z.V. 1991. Metode Perancangan Percobaan untuk Ilmu-ilmu Pertanian, Ilmu-ilmu Teknik, dan Biologi. Penerbit C.V. Armico. Bandung

Hanafiah K.A. 1991. Rancangan Percobaan. Teori dan Aplikasi. Penerbit Rajawali Pers. Jakarta.

Heikkellae V.T., R. Gronovist \& M. Jurvalius. 1993. Hand Book on Forest Fire Control. Forestry Training Program Finland. Helsinki.

IFFM. 2003. Mencari Strategi Kampanye Pencegahan Kebakaran Hutan. Prosiding workshop Pencegahan Kebakaran Hutan, Proyek Uni- Eropah (SCKPFP). Banjarbaru.

Sagala APS. 1992. Mengendalikan Api Lahan. Publikasi Khusus. Balai Teknologi Reboisasi Banjarbaru. Banjarbaru.

Saharjo B.H. 2006. Teknologi Pengelolaan dan Pengolahan Lahan Gambut Tanpa Pembakaran di Lahan Masyarakat. Makalah Seminar Nasional Pencegahan, Penanggulangan dan Penindakan Terhadap Pelaku Pembakaran Hutan, Lahan dan Pekarangan 19-20 Desember 2006. Palangka Raya.

Sastrawijaya. A.T. 1991. Pencemaran Lingkungan. Penerbit Rineka Cipta. Jakarta. 
Suyanto, S., R.P. Permana, J. Setijono, G. Applegote. 2001. Kebijakan Pengelolaan Sumber Daya Alam dan Aktivitas Sosial Ekonomi Dalam Kaitannya Dengan Penyebab dan Dampak Kebakaran Hutan dan Lahan di Sumatera. Prosiding Akar Penyebab dan Dampak Kebakaran Hutan dan Lahan di Sumatera. Bandar Lampung 11 Oktober 2001

Temmes, M. 1992. Reforestation Operation Manual for Alang-alang Grasslands. Reforestation and Tropical Forest Management Project ATA-267. Banjarbaru

Wibowo, A. 1997. Memahami Perilaku Pembakaran Hutan. Duta Rimba Edisi 205-206. Hal 18-24. Perum Perhutani. Jakarta. 